M.F. Mehdi, A. Ahmad, S.S. Ul Haq, M. Saqib, M.F. Ullah

\title{
DYNAMIC ECONOMIC EMISSION DISPATCH USING WHALE OPTIMIZATION ALGORITHM FOR MULTI-OBJECTIVE FUNCTION
}

\begin{abstract}
Introduction. Dynamic Economic Emission Dispatch is the extended version of the traditional economic emission dispatch problem in which ramp rate is taken into account for the limit of generators in a power network. Purpose. Dynamic Economic Emission Dispatch considered the treats of economy and emissions as competitive targets for optimal dispatch problems, and to reach a solution it requires some conflict resolution. Novelty. The decision-making method to solve the Dynamic Economic Emission Dispatch problem has a goal for each objective function, for this purpose, the multi-objective problem is transformed into single goal optimization by using the weighted sum method and then control/solve by Whale Optimization Algorithm. Methodology. This paper presents a newly developed metaheuristic technique based on Whale Optimization Algorithm to solve the Dynamic Economic Emission Dispatch problem. The main inspiration for this optimization technique is the fact that metaheuristic algorithms are becoming popular day by day because of their simplicity, no gradient information requirement, easily bypass local optima, and can be used for a variety of other problems. This algorithm includes all possible factors that will yield the minimum cost and emissions of a Dynamic Economic Emission Dispatch problem for the efficient operation of generators in a power network. The proposed approach performs well to perform in diverse problem and converge the solution to near best optimal solution. Results. The proposed strategy is validated by simulating on MATLAB ${ }^{\circledR}$ for 5 IEEE standard test system. Numerical results show the capabilities of the proposed algorithm to establish an optimal solution of the Dynamic Economic Emission Dispatch problem in a several runs. The proposed algorithm shows good performance over the recently proposed algorithms such as Multi-Objective Neural Network trained with Differential Evolution, Particle swarm optimization, evolutionary programming, simulated annealing, Pattern search, multi-objective differential evolution, and multi-objective hybrid differential evolution with simulated annealing technique. References 17, tables 3, figures 5.
\end{abstract}

Key words: whale optimization algorithm, dynamic economic emission dispatch, ramp rate, multi-objective problem, economic emission.

Вступ. Динамічна економна диспетчеризація викидів - ие розиирена версія традиційної задачі економної диспетчеризації викидів, в якій враховується коефіцієнт нарощування для межі генераторів в енергомережі. Призначення. Динамічна економна диспетчеризація викидів розглядала питання економії та викидів як конкурентні иілі для оптимальних задач диспетчеризації, $і$ для розв 'язання задачі потрібне певне вирімення конфліктів. Новизна. Метод прийняття рішень для розв язання задачі динамічної економної диспетчеризації викидів має мету для кожної иільової функиії, для иього багатоиільова задача трансформується в оптимізаиію однієї иілі за допомогою методу зваженої суми, а потім контролюється/розв язується за допомогою алгоритму оптимізаиії китів. Методологія. У цій роботі представлена нещодавно розроблена метаевристична методика, заснована на алгоритмі оптимізації китів для розв'язання задачі динамічної економної диспетчеризації викидів. Основним натхненням для иієї методики оптимізаиії є той факт, щяо метаевристичні алгоритми стають популярними з кожним днем завдяки своїй простоті, відсутності вимог до інформачіі про градієнт, легкості обходу локальних оптимумів та можливості бути використаними для ряду інших задач. Цей алгоритм включає в себе всі можливі фактори, які забезпечать мінімальні вартість та викиди задачі динамічної економноі диспетчеризаиії викидів для ефективної роботи генераторів в енергомережі. Запропонований підхід добре праиює для розв 'язання задач і наближення рішення до найкращого оптимального. Результати. Запропонована стратегія перевірена иляхом моделювання на МАTLAB ${ }^{\circledR}$ для 5 стандартних тестових систем IEEЕ. Чисельні результати демонструють можливості запропонованого алгоритму для встановлення оптимального рімення задачі динамічної економної диспетчеризації викидів за кілька прогонів. Запропонований алгоритм демонструє хорошу ефективність порівняно 3 нещодавно запропонованими алгоритмами, такими як багатоцільова нейронна мережа, навчена з використанням диференціальної еволючії, оптимізація рою частинок, еволюиійне програмування, імітаційний відпал, пошук за шаблоном, багатойільова диференціальна еволючія та багатойільова гібридна диференціальна еволюиія з імітаційним методом відпалу. Бібл. 17, табл. 3, рис. 5 .

Ключові слова: алгоритм оптимізації китів, динамічна економна диспетчеризація викидів, швидкість наростання, багатоцільова задача, економна емісія.

1. Introduction. Power plants based on fossil fuel emit health hazardous gases into the surrounding environment. Air pollution due to these gases can not only affect human life but can compromise the animals and birds life. It also damages visibility, material quality, and causing global warming [1]. With increasing environmental concern, consumer demands high quality power with safe electricity, at lowest possible rates and with lowest possible pollution. Dynamic Economic Emission Dispatch (DEED) provide a solution to these problem by scheduling the renewable and backup power sources based on the forecast load demand to reduce cost and emission of the operating generator $[2,3]$.

DEED is dynamic in nature due to non-linear nature of power system and its loads. This non-linear or dynamic problem is normally solved by discretizing the whole dispatch time interval into smaller time interval in which the load is serve as constant and in steady state. To control and achieve the lowest cost and emission ratio, the individual time interval must be dispatched so that to minimize the cost and emission at that time subjected to static constraint with additional time limit known as dynamic constraint. DEED is serve as an accurate method to solve economic dispatch (ED) problem but at same time it is the most difficult method due to lengthy measurements [4].

Nowadays, meta-heuristic optimization algorithms are gaining popularity in engineering and technology field

(C) M.F. Mehdi, A. Ahmad, S.S. Ul Haq, M. Saqib, M.F. Ullah 
due to its simplicity and easy to implement concept. No gradient information is required for their implementation. Not only can they circumvent regional optimizations, but they can also be applied to numerous fields [5].

In recent years, probabilistic search algorithms e.g. genetic algorithms (GA), simulated annealing (SA), and evolutionary programming (EP) are efficiently utilized to solve power network optimization issues. These methods aren't based on 1st and 2nd differences in the objective function of optimized problem [6, 7].

1. Literature review. In [8] solved the multipurpose economic emission dispatch problem using a new technique called Dance Bee Colony with dynamic step size taking into account the valve point effect. The proposed algorithm was applied to the 6 unit and 40 unit systems, respectively. He observed that the proposed method could also solve the combined economic emission dispatch problem. In [9] studied DEED, which contains uncertainties in the development process. In addition to the classic dynamic economic emissions dispatch factor, reliability and efficiency constraints have been specifically considered to contain the disturbances of uncertainty. As a result, a fine and reserve emission function has been added to the multipurpose function as well as a fine and reserve cost function. To obtain quantitative results, we discussed the characterization of various sources of uncertainty based on statistical theory, and this optimization problem was solved numerically by an improved particle cluster optimization algorithm. In [10] announced the multi-elite guided hybrid differential evolution using a simulated annealing technique for dynamic economic emission dispatch (MOHDE-SAT). This incorporates orthogonal initialization methods into differential evolution, expanding population diversity early in the population.

In addition, we can use modified mutation operators and archive preservation mechanisms to control the rate of convergence, and adaptively monitor population diversity as evolution progresses using simulated annealing techniques and entropy diversity methods to adequately avoid early convergence problems.

Applied to 5 and 10 unit systems. In [11] versatile DEED using the PSO variant was announced. Tested PSO variants include standard PSO (SPSO), worst-case avoidance PSO (PSO AWL), and progressively increasing directional neighbors (PSO GIDNs). Researchers tested the performance of various variants of PSO AWL against variants of SPSO for DEED problems and concluded that PSO AWL outperformed SPSO for all implemented topologies.

Applied to 10 units. In 2018 a new multipurpose neural network trained with MONNDE (Differential Evolution) was presented in [12]. The MONNDE framework applies to the problem of Dynamic Economic Emission Dispatch (DEED) and is equally optimal compared to other state-of-the-art algorithms in terms of 24-hour cost and emissions. Researchers also compared the performance of fully connected and partially connected networks and found that dynamically optimizing the topology of a neural network performed better in an online learning environment than simply optimizing the network weights.
It is clear from the literature that the problem of economic emission dispatch is solved with many classical, meta-heuristic and hybrid techniques.

Another newly developed technique called Whale Optimization Algorithm (WOA) is proposed. This method has not yet been implemented in the DEED problem, but it could be a very attractive idea to use this algorithm for the DEED problem. Our focus is on applying WOA to standard test systems.

This paper develops efficient and reliable evolutionary programming based on WOA to solve the DEED problem. Here the objective functions, namely cost and emissions, are modeled. The proposed strategy is validated by simulating MATLAB ${ }^{\circledR}$ against 5 IEEE standard test system. Numerical results for a sample test system are presented to demonstrate the capabilities of the proposed approach to create a well-distributed Pareto optimal solution of the dynamic economic emission dispatch problem in a single run. The proposed algorithm is also compare with the recently proposed algorithms such as Multi-Objective Neural Network trained with Differential Evolution (MONNDE), particle swarm optimization (PSO), evolutionary programming (EP), simulated annealing (SA), Pattern search (PS), multiobjective differential evolution (MODE), and multiobjective hybrid differential evolution with simulated annealing technique (MOHDE-SAT).

2. Problem formulation. The DEED problem is flexible mathematical programming problem that consists of goals and constraints to achieve lowest cost and emission at a time. To achieve the above goal, the system equality and inequality constraints should be met. Steps involving in DEED problem are given below.

2.1. Objectives function of DEED problem. Objectives function of DEED problem consists of fuel cost and emission functions.

2.1.1 Economy. The cost function $F_{1}$ shows the hourly cost of power generators and is given as:

$$
F_{1}=\sum_{i=1}^{N} \sum_{m=1}^{N} F_{i}\left(P_{i}\right),
$$

where $N$ refers to power generators numbers.

Equation (2) shows the cost hourly non-convex cost function of power generators:

$$
\begin{aligned}
& F_{i}\left(P_{i}\right)=a_{i}+b_{i} P_{i}+c_{i} P_{i}^{2}+ \\
& +\mid e_{i} \cdot \sin \left(f_{i}\left(P_{\min , i}+P_{m}\right) \mid\right),
\end{aligned}
$$

where $m$ is the present hour; $a_{i}, b_{i}, c_{i}, e_{i}$ and $f_{i}$ are all constant factors related with each generator $i ; P_{\min , i}$ is the minimum power output of a generator $i$ at $m$ time and $P_{\text {min }}$ is the minimum power of a generator.

2.1.2 Emission. The emission function $F_{2}$ that determine the total hazardous pollutant produce due to operation of all generators per hours as shown in equation:

$$
F_{2}=\sum_{i=1}^{N} \sum_{m=1}^{N} E_{i}\left(P_{i}\right),
$$

where the emission function $E$ determines the amount of injurious pollutants produce by power generators for 24 hours.

Equation (4) shows the harmful pollutants of nonconvex function 


$$
E_{i}\left(P_{i}\right)=\alpha_{i}+\beta_{i} P_{i}+\gamma_{i} P_{i}^{2}+\delta_{i} \exp \left(\lambda_{i} P_{i}\right)
$$

where $\alpha_{i}, \beta_{i}, \gamma_{i}, \delta_{i}$ and $\lambda_{i}$ are the emission constant factors related with each generator $i$.

2.2 Constraints. DEED constraint consists of equality and inequality constraints.

2.2.1 Balance Constraints. All solution is substance to real power equality constraint. Balance constraint is define as the total output power must be equal to summation of actual power demand and losses due to transmission lines as shown in equations (5) and (6)

$$
\begin{gathered}
\sum_{i=1}^{N} P_{i}=P_{o m}+P_{l m}, \\
P_{l m}=\sum_{i=1}^{n} \sum_{j=1}^{n} P_{i} B_{i, j} P_{j}+\sum_{i=1}^{n} B_{i 0} P_{i}+B_{00},
\end{gathered}
$$

where $B_{i, j}, B_{i 0}$ and $B_{00}$ are the loss coefficients of generators.

\subsubsection{Inequality constraints.}

2.2.2.1 Operating limit for each power generator. It determines the possible upper and lower power output of each generator in a network. The operating limits for each generator are defined as:

$$
P_{i}^{\min } \leq P_{i m} \leq P_{i}^{\max },
$$

where $P_{i}^{\max }$ and $P_{i}^{\min }$ are the maximum and minimum power output of each generator respectively.

2.2.2.2 Ramp rate limits of generating unit. The ramp limits of any generator determine the increase or decrease of maximum allowed output power between specific two limit steps. It can be define by follow equations:

$$
\begin{aligned}
& P_{i m}-P_{i(m-1)} \leq U R_{i}, \\
& P_{i(m-1)}-P_{i m} \leq D R_{i},
\end{aligned}
$$

where $U R_{i}$ is the up ramp limit of a generator while $D R_{i}$ are down ramp limit for a generator.

3. Principle of Whale Optimization Algorithm. WOA is inspire from the humpback whale hunting, which is also called bubble net feeding. This algorithm emphasizes the method of intelligent hunting mechanism of that particular whale. They hunt in a groups (size up to 12 whales), while the group leader is finding the group of fish to hunt [13]. Figure 1 shows the Bubble-net feeding behavior of humpback whales to hunt small fishes.

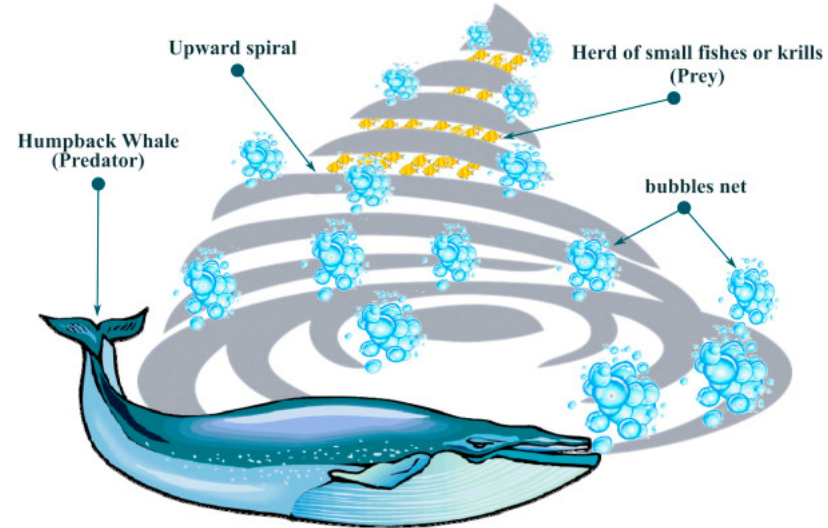

Fig. 1. Bubble-net feeding behavior of humpback whales [14]
The group of humpback whale goes under water and start to blow bubble while leader whale create larger size bubble in shape of « 9 ». The fishes trapped in 9 shape trap due to its irregular swimming. Now the group of whale comes out with their mouths open and start hunting the trapped fishes inside the spiral bubbles. This technique of feeding is the unique behavior of this particular whale. In this research work, the bubble feed mechanism is modeled and implemented for solving the DEED problem.

The WOA approach starts with a function containing set of random solutions. The search agent update its position or location at each iteration based on randomly selected searches or best solution obtained. An «a» parameter is used in this method, whose value is normally reduced from 2 into 0 to achieve exploration and its utilization. Their value is adjusted every time to achieve best possible solution, finally the WOA is terminated when the solution meet the desire criteria.

4. Proposed whale optimization algorithm. The WOA is based on humpback whale hunting technology. Whales are mostly considered predators. Their favorite prey is hunting small group of fishes. The best thing about the humpback whale is their method of preying.

WOA algorithm involves steps such as encircling prey, bubble net feeding method, exploration phase and finally its implementation.

4.1 Encircling prey. Humpback whales can identify the position if prey and encircle them. Usually the location of optimal design is known, so the WOA algorithm that the current position is the best solution of targeted prey. After that starts to search for other best solution. If new best solution fined then the previous one updated with new best search agent. The encircling prey process can be expressed by equations:

$$
\begin{gathered}
\vec{D}=\left|\vec{C} X^{*}(t)-\vec{X}(t)\right| ; \\
\vec{X}(t+1)=\overrightarrow{X^{*}}(t)-\vec{A} \vec{D},
\end{gathered}
$$

where the term $t$ shows the up-to-date iteration; $\vec{A}$ and $\vec{C}$ are constant vectors, $\overrightarrow{X^{*}}$ is the position vector of the best solution obtained up-to-dated; $\vec{X}$ is the location vector.

It is important that $\overrightarrow{X^{*}}$ should be updated in each iteration if there is a better solution.

The vectors $\vec{A}$ and $\vec{C}$ are considered as shown in equations:

$$
\begin{gathered}
\vec{A}=2 \vec{a} \cdot \vec{r}, \\
\vec{C}=2 \vec{r},
\end{gathered}
$$

where vector $\vec{a}$ is linearly decreased from 2 to 0 in individual iterations (both in exploration and exploitation phases) and $\vec{r}$ is a random vector in $[0,1]$.

4.2 Exploitation phase. It is also called Bubble-net attacking method. This step consists of two processes.

4.2.1 Shrinking encircling mechanism. Shrinking encircling mechanism is accomplished by reducing the value of operator $\vec{a}$. This behavior is achieved by decreasing the value of $\vec{a}$. Due to this $\vec{A}$ will also 
decreased in fact. $\vec{A}$ is an interval $[-\vec{a}, \vec{a}]$ having random value between $\pm \vec{a}$. The new location of search agent is selected between reference location of agent and location of present best agent.

4.2.2 Spiral updating position. The spiral position is lie between the whale position and its prey that causes the helix shaped movement of whale as shown in follow equation:

$$
\vec{X}(t+1)=\overrightarrow{D^{\prime}} e^{b \cdot l} \cos (2 \pi l)+\overrightarrow{X^{*}}(t),
$$

where $\overrightarrow{D^{\prime}}=|\vec{X} *(t)-\vec{X}(t)|$ and indicates the distance of the $i$-th whale to the prey (best solution obtained so far); $b$ is a constant for defining the shape of the logarithmic spiral; $l$ is a random number in $[-1,1]$.

Humpback whales swim around the prey within a shrinking circle and along a spiral-shaped path simultaneously. The mathematical model spiral behavior has a probability of $50 \%$ because the value of operator $\vec{a}$ decide whether the movement will be circular or spiral. Follow equations shown this spiral behavior:

$$
\begin{gathered}
\vec{X}(t+1)=\overrightarrow{X^{*}}(t)-\vec{A} \vec{D} \quad \text { if } \quad P<0.5, \\
\vec{X}(t+1)=\overrightarrow{D^{\prime}} e^{b \cdot l} \cos (2 \pi l)+\overrightarrow{X^{*}}(t) \quad \text { if } \quad P \geq 0.5,
\end{gathered}
$$

where $P$ is a random number in $[0,1]$.

In addition to the bubble-net method, the humpback whales search for prey randomly.

4.3 Search for prey (exploration phase). This is an exploration phase where humpback whales randomly search for each other position. So, $\vec{A}$ having random value of greater or less than \pm 1 forces the search agent to move far from reference position of reference whale. The exploration phase in this case can be calculated by follow equations:

$$
\begin{gathered}
\vec{D}=\left|\vec{C} \vec{X}_{\text {rand }}-\vec{X}\right|, \\
\vec{X}(t+1)=\vec{X}_{\text {rand }}-\vec{A} \vec{D} .
\end{gathered}
$$

In the exploration phase according to a randomly chosen search agent instead of the best search agent found so far.

4.4 Implementation of WOA. The implementation of WOA is represented through flow chart in Fig. 2.

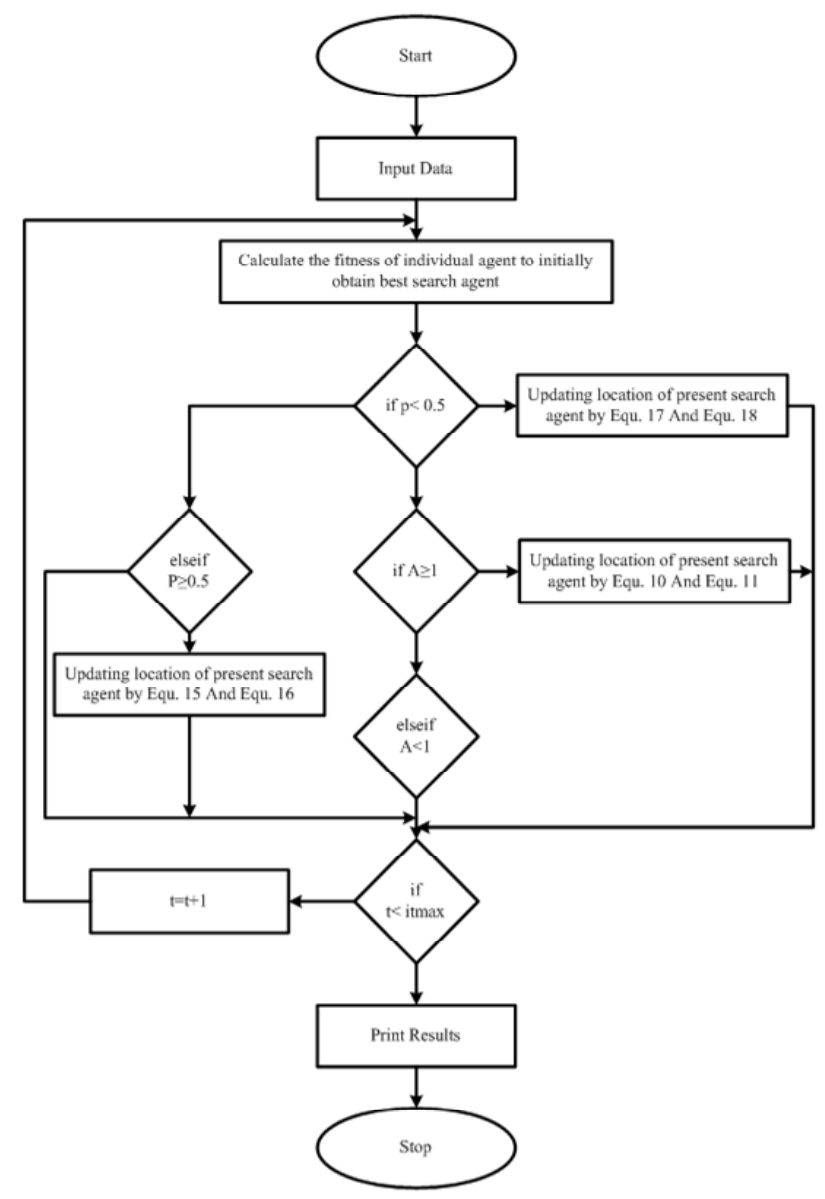

Fig. 2. The flowchart of proposed WOA

5. The simulation of the proposed multiobjective algorithm. The analyses were performed including minimum cost and emission ratio for operation of generators in a power network to show the improved performance of proposed algorithm. Furthermore, the effectiveness of proposed algorithm is checked by comparing with recently proposed algorithms such as MONNDE, PSO, EP, SA, PS, MODE, and MOHDESAT. All the analysis were done using MATLAB ${ }^{\circledR}(2018$ Version) on an Intel (R) Core (TM) i5-2520M processor $2.50 \mathrm{GHz}$ with a RAM 4.00 GB. Subsequent sections show the test system parameters and results after analysis.

5.1 Test system and its parameters. The proposed algorithm is tested on IEEE 5 units. The parameter of IEEE 5 units is shown in Table 1.

Table 1

Test System 1: 5 units IEEE data

\begin{tabular}{|c|c|c|c|c|c|c|c|c|c|c|c|c|c|c|}
\hline Unit & $\begin{array}{c}P_{\min }, \\
\mathrm{MW}\end{array}$ & $\begin{array}{c}P_{\max }, \\
\mathrm{MW}\end{array}$ & $\begin{array}{c}U R, \\
\mathrm{MW} / \mathrm{h}\end{array}$ & $\begin{array}{c}D R, \\
\mathrm{MW} / \mathrm{h}\end{array}$ & $\begin{array}{c}a, \\
\$ / \mathrm{h}\end{array}$ & $\begin{array}{c}b, \\
\$ / \mathrm{MWh}\end{array}$ & $\begin{array}{c}c, \\
\$ / \mathrm{MW}^{\wedge} 2 \mathrm{~h}\end{array}$ & $\begin{array}{c}e, \\
\mathrm{rad} / \mathrm{MW}\end{array}$ & $\begin{array}{c}f, \\
\mathrm{lb} / \mathrm{h}\end{array}$ & $\begin{array}{c}\alpha, \\
\mathrm{lb} / \mathrm{MWh}\end{array}$ & $\begin{array}{c}\beta, \\
\mathrm{lb} / \mathrm{MWh}\end{array}$ & $\begin{array}{c}\gamma, \\
\mathrm{b} / \mathrm{MW}^{\wedge} 2 \mathrm{~h}\end{array}$ & $\begin{array}{c}\delta, \\
\mathrm{lb} / \mathrm{h}\end{array}$ & $\begin{array}{c}\lambda, \\
1 / \mathrm{MW}\end{array}$ \\
\hline 1 & 10 & 75 & 30 & 30 & 25 & 2.0 & 0.0080 & 100 & 0.042 & 80 & -0.805 & 0.0180 & 0.6550 & 0.02846 \\
\hline 2 & 20 & 125 & 30 & 30 & 60 & 1.8 & 0.0030 & 140 & 0.040 & 50 & -0.555 & 0.0150 & 0.5773 & 0.02446 \\
\hline 3 & 30 & 175 & 40 & 40 & 100 & 2.1 & 0.0012 & 160 & 0.038 & 60 & -1.355 & 0.0105 & 0.4968 & 0.02270 \\
\hline 4 & 40 & 250 & 50 & 50 & 120 & 2.0 & 0.0010 & 180 & 0.037 & 45 & -0.600 & 0.0080 & 0.486 & 0.01948 \\
\hline 5 & 50 & 300 & 50 & 50 & 40 & 1.8 & 0.0015 & 200 & 0.035 & 30 & -0.555 & 0.0120 & 0.5035 & 0.02075 \\
\hline
\end{tabular}

5.2 Results and comparisons. Table 2 shows the best fuel cost and emission for 24 hours for given load. The value of P1-P5 is selected by WOA such that load demand is fulfilled and give best fuel cost and emission result.
The 5 units test system is simulated for 8 trails having 500 search agents for 100 iterations. Table 3 presents the best cost, best emission and total costemission against 0.5 weight for 5 units. The results shown 
in Table 3 are obtained from MONNDE, PSO, EP, SA, PS, MODE, MOHDE-SAT and proposed technique. The percentage change of other techniques with respect to proposed algorithm shows the effectiveness of proposed WOA. The proposed WOA has $4.94 \%$ better performance than MONNDE, $8.8 \%$ than PSO, $6.85 \%$ than EP, $6.9 \%$ than SA, $2.35 \%$ than PS, $0.218 \%$ than MODE, and $1.411 \%$ than MOHDE-SAT.

Table 2

DEED results for $24 \mathrm{hrs}$

\begin{tabular}{|c|c|c|c|c|c|c|c|c|}
\hline Load & Hour & P1 & P2 & P3 & P4 & P5 & Fuel Cost & Emission \\
\hline 410 & 1 & 17.70 & 106.91 & 112.46 & 40 & 136.54 & 1317.87 & 510.62 \\
\hline 435 & 2 & 45.71 & 98.84 & 118.13 & 40 & 136.30 & 1438.52 & 505.75 \\
\hline 475 & 3 & 75 & 103.50 & 119.50 & 40 & 141.74 & 1515.83 & 579.21 \\
\hline 530 & 4 & 75 & 98.79 & 127.53 & 89.81 & 144.58 & 1847.63 & 610.53 \\
\hline 558 & 5 & 75 & 103.41 & 118.83 & 125.94 & 141.13 & 1697.07 & 643.38 \\
\hline 608 & 6 & 75 & 98.51 & 130.10 & 168.47 & 143.39 & 2038.01 & 735.64 \\
\hline 626 & 7 & 75 & 100.18 & 114.38 & 205.46 & 139.05 & 1832.18 & 806.98 \\
\hline 654 & 8 & 75 & 102.71 & 133.92 & 209.16 & 141.95 & 2005.68 & 862.69 \\
\hline 690 & 9 & 75 & 108.91 & 166.54 & 208.41 & 140.79 & 2153.24 & 944.19 \\
\hline 704 & 10 & 73.88 & 106.36 & 171.88 & 209.76 & 152.17 & 2226.74 & 989.75 \\
\hline 720 & 11 & 75 & 102.64 & 174.99 & 227.19 & 150.71 & 2329.29 & 1048.01 \\
\hline 740 & 12 & 75 & 98.54 & 172.96 & 211.59 & 192.96 & 2380.45 & 1142.23 \\
\hline 704 & 13 & 75 & 117.91 & 172.33 & 204.43 & 144.36 & 2261.61 & 985.77 \\
\hline 690 & 14 & 75 & 104.04 & 166.28 & 213.28 & 141.05 & 2143.43 & 946.84 \\
\hline 654 & 15 & 75 & 99.92 & 140.69 & 205.44 & 141.66 & 2037.19 & 854.35 \\
\hline 580 & 16 & 75 & 99.24 & 111.07 & 155.44 & 146.10 & 1886.79 & 691.40 \\
\hline 558 & 17 & 75 & 105.60 & 118.75 & 126.29 & 138.68 & 1709.21 & 642.50 \\
\hline 608 & 18 & 75 & 101.05 & 126.35 & 168.89 & 144.21 & 2038.31 & 739.96 \\
\hline 654 & 19 & 75 & 96.31 & 142.14 & 211.06 & 138.20 & 2023.64 & 856 \\
\hline 704 & 20 & 75 & 113.52 & 171.41 & 211.85 & 142.31 & 2209.86 & 987.26 \\
\hline 680 & 21 & 75 & 93.37 & 169.87 & 211.95 & 139.17 & 2092.81 & 918.93 \\
\hline 605 & 22 & 75 & 105.93 & 129.87 & 161.95 & 139.68 & 2043.15 & 729.03 \\
\hline 527 & 23 & 59.21 & 94.35 & 113.33 & 124.72 & 141.03 & 1615.60 & 583.67 \\
\hline 463 & 24 & 45.06 & 97.89 & 111.04 & 74.72 & 138.70 & 1631 & 513.30 \\
\hline $\mathbf{1 4 5 7 7}$ & & & & & & $\mathbf{4 6 4 7 5 . 1 0}$ & $\mathbf{1 8 8 2 7 . 9 9}$ \\
\hline
\end{tabular}

Table 3

Performance comparison of WOA with other algorithms

\begin{tabular}{|c|c|c|c|c|}
\hline Technique & $\begin{array}{c}\text { Best cost } \\
(\$)\end{array}$ & $\begin{array}{c}\text { Best emission } \\
(\mathrm{lbs})\end{array}$ & $\begin{array}{c}\text { Total } \\
(0.5 \text { weight })\end{array}$ & $\begin{array}{c}\text { Change \% } \\
\text { w.r.t WOA }\end{array}$ \\
\hline $\begin{array}{c}\text { MONNDE } \\
{[12]}\end{array}$ & 49135 & 18233 & 33684.24 & 4.94 \\
\hline PSO [15] & 50893 & 20163 & 35528 & 8.80 \\
\hline EP [16] & 48628 & 21154 & 34891 & 6.85 \\
\hline SA [10] & 48621 & 21188 & 34904.5 & 6.90 \\
\hline PS [17] & 47911 & 18927 & 33419 & 2.35 \\
\hline MODE [10] & 47330 & 18116 & 32723 & 0.218 \\
\hline $\begin{array}{c}\text { MOHDE- } \\
\text { SAT [10] }\end{array}$ & 48214 & 18011 & 33112.5 & 1.411 \\
\hline $\begin{array}{c}\text { Proposed } \\
\text { WOA }\end{array}$ & 46475.09 & 18827.98 & 32651.53 & - \\
\hline
\end{tabular}

Figure 3 shows the graphical comparison of total cost and emission of proposed algorithms and other algorithms for 5 units. This clearly shows that the proposed WOA has the minimum total cost and emission than other algorithms.

Percentage improvement of proposed WOA with respect to other algorithms is shown in Fig. 4.

Figure 5 shows the variation of best cost among 8 trails (500 search agent and 100 iterations). Total cost and emission for each trail is $32761.39457,32691.25187$, 32870.03513 , 32843.87755, 32824.84763, 33220.30359, 32651.54342, and 32745.05286, respectively. The best cost and emission is obtain at trail 7, which is 32651.54342 .

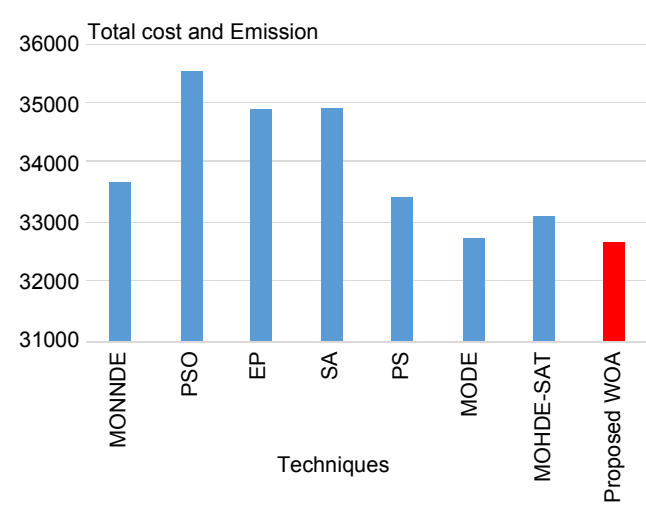

Fig. 3. Graphical comparison of total cost and emission vs. techniques

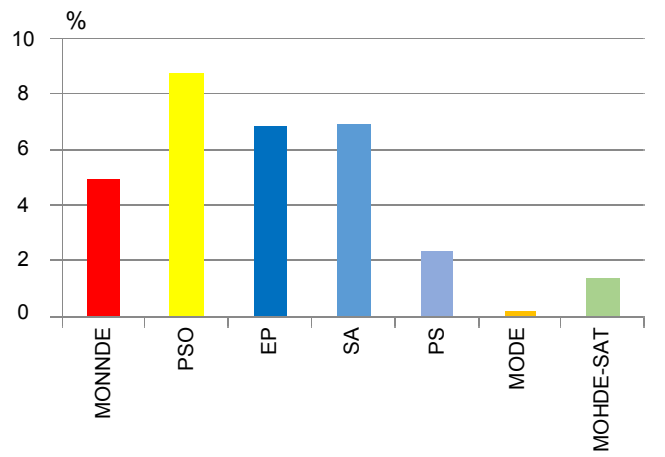

Fig. 4. Percentage improvement of proposed WOA vs. other techniques

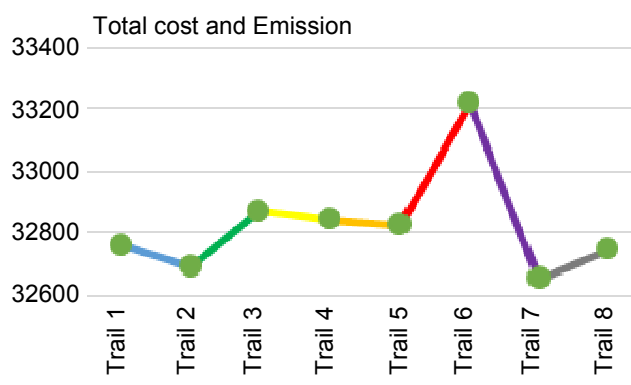

Fig. 5. Variation of best cost among 8 trails

\section{Conclusion.}

This paper presents a newly developed metaheuristic technique based on Whale Optimization Algorithm to solve the Dynamic Economic Emission Dispatch problem. The main inspiration for this optimization method is the fact that Metaheuristic algorithms are easy to implement, no gradient information requirement, easily bypass local optima, and can be used for a variety of other problems. The proposed strategy is validated by simulating on MATLAB $^{\circledR}$ for 5 IEEE standard test system. Numerical results for the 5 IEEE test system are presented to show the capabilities of the proposed algorithm to establish an optimal solution of the Dynamic Economic Emission Dispatch problem in a several runs. The proposed Whale Optimization Algorithm for 5 unit has $4.94 \%$ better performance than Multi-Objective Neural Network trained with Differential Evolution, 8.8 $\%$ than Particle swarm optimization, $6.85 \%$ than evolutionary programming, $6.9 \%$ than simulated annealing, $2.35 \%$ than Pattern search, $0.218 \%$ than 
multi-objective differential evolution, and $1.411 \%$ than multi-objective hybrid differential evolution with simulated annealing technique.

Conflict of interest. The authors declare that they have no conflicts of interest.

\section{REFERENCES}

1. Zou Y., Zhao J., Ding D., Miao F., Sobhani B. Solving dynamic economic and emission dispatch in power system integrated electric vehicle and wind turbine using multiobjective virus colony search algorithm. Sustainable Cities and Society, 2021, vol. 67, p. 102722. doi: https://doi.org/10.1016/j.scs.2021.102722.

2. Zare M., Narimani M.R., Malekpour M., AzizipanahAbarghooee R., Terzija V. Reserve constrained dynamic economic dispatch in multi-area power systems: An improved fireworks algorithm. International Journal of Electrical Power \& Energy Systems, 2021, vol. 126, part A, p. 106579. doi: https://doi.org/10.1016/j.ijepes.2020.106579.

3. Ahmed W., Sheikh J.A., Kouzani A.Z., Mahmud M.A.P. The Role of Single End-Users and Producers on GHG Mitigation in Pakistan - A Case Study. Sustainability, 2020, vol. 12, no. 20, p. 8351. doi: https://doi.org/10.3390/su12208351.

4. Qian S., Wu H., G Xu. An improved particle swarm optimization with clone selection principle for dynamic economic emission dispatch. Soft Computing, 2020, vol. 24, no. 20, pp. 15249-15271. doi: https://doi.org/10.1007/s00500-020-04861-4.

5. Azizivahed A., Arefi A., Naderi E., Narimani H., Fathi M., Narimani M.R. An Efficient Hybrid Approach to Solve Bi-objective Multi-area Dynamic Economic Emission Dispatch Problem. Electric Power Components and Systems, 2020, vol. 48, no. 4-5, pp. 485-500. doi: https://doi.org/10.1080/15325008.2020.1793830.

6. Wu C., Jiang P., Sun Y., Zhang C., Gu W. Economic dispatch with CHP and wind power using probabilistic sequence theory and hybrid heuristic algorithm. Journal of Renewable and Sustainable Energy, 2017, vol. 9, no. 1, p. 013303. doi: https://doi.org/10.1063/1.4976144.

7. Zhang Y., Liu K., Liao X., Qin L., An X. Stochastic dynamic economic emission dispatch with unit commitment problem considering wind power integration. International Transactions on Electrical Energy Systems, 2018, vol. 28, no. 1, p. e2472. doi: https://doi.org/10.1002/etep.2472.

8. Hadji B., Mahdad B., Srairi K., Mancer N. Multi-objective economic emission dispatch solution using dance bee colony with dynamic step size. Energy Procedia, 2015, vol. 74, pp. 65-76. doi: https://doi.org/10.1016/j.egypro.2015.07.524.

9. Jin J., Zhou D., Zhou P., Guo X., Sun Z. Modeling for dynamic economic emission dispatch under uncertainty. Electric Power Components and Systems, 2015, vol. 43, no. 14, pp. 16301643. doi: https://doi.org/10.1080/15325008.2015.1050613.

10. Zhang H., Yue D., Xie X., Hu S., Weng S. Multi-elite guide hybrid differential evolution with simulated annealing technique for dynamic economic emission dispatch. Applied Soft Computing, 2015, vol. 34, pp. 312-323. doi: https://doi.org/10.1016/j.asoc.2015.05.012.
11. Mason K., Duggan J., Howley E. Multi-objective dynamic economic emission dispatch using particle swarm optimisation variants. Neurocomputing, 2017, vol. 270, pp. 188-197. doi: https://doi.org/10.1016/j.neucom.2017.03.086.

12. Mason K., Duggan J., Howley E. A multi-objective neural network trained with differential evolution for dynamic economic emission dispatch. International Journal of Electrical Power \& Energy Systems, 2018, vol. 100, pp. 201-221. doi: https://doi.org/10.1016/j.ijepes.2018.02.021.

13. Mirjalili S., Lewis A. The whale optimization algorithm. Advances in Engineering Software, 2016, vol. 95, pp. 51-67. doi: https://doi.org/10.1016/j.advengsoft.2016.01.008.

14. Hassan M.K., El Desouky A.I., Elghamrawy S.M., Sarhan A.M. A Hybrid Real-time remote monitoring framework with NB-WOA algorithm for patients with chronic diseases. Future Generation Computer Systems, 2019, vol. 93, pp. 77-95. doi: https://doi.org/10.1016/j.future.2018.10.021.

15. Basu M. Particle swarm optimization based goal-attainment method for dynamic economic emission dispatch. Electric Power Components and Systems, 2006, vol. 34, no. 9, pp. 10151025. doi: https://doi.org/10.1080/15325000600596759.

16. Basu, M. (). Dynamic economic emission dispatch using evolutionary programming and fuzzy satisfying method. International Journal of Emerging Electric Power Systems, 2007, vol. 8, no. 4, Article 1. doi: https://doi.org/10.2202/1553779X.1146.

17. Alsumait J.S., Qasem M., Sykulski J.K., Al-Othman A.K. An improved pattern search based algorithm to solve the dynamic economic dispatch problem with valve-point effect. Energy Conversion and Management, 2010, vol. 51, no. 10, pp. 20622067. doi: https://doi.org/10.1016/j.enconman.2010.02.039.

Received 03.11.2020

Accepted 13.12.2020

Published 05.04.2021

Muhammad Faizan Mehdi ${ }^{1}$, MS in Electrical Engineering, Aftab Ahmad ${ }^{1}$, Professor,

Syed Sadam Ul Haq ${ }^{1}, M S$ in Electrical Engineering,

Muhammad Saqib ${ }^{1}, M S$ in Electrical Engineering,

Mian Farhan Ullah ${ }^{2}$, Engineer, Junior Lecturer,

${ }^{1}$ Department of Electrical Engineering,

University of Engineering and Technology, Taxila, Pakistan, e-mail: faizan.mehdi8545@gmail.com,

aftab.ahmad@uettaxila.edu.pk,ssadamulhaq@gmail.com

engrsaqibkhan93@gmail.com

${ }^{2}$ Department of Electrical Engineering,

Wah Engineering College, University of Wah,

Quaid Avenue, Wah Cantt, Rawalpindi District,

Punjab 47040, Pakistan,

e-mail: farhan.ullah@wecuw.edu.pk

How to cite this article:

Mehdi M.F., Ahmad A., Ul Haq S.S., Saqib M., Ullah M.F. Dynamic economic emission dispatch using whale optimization algorithm for multi-objective function. Electrical Engineering \& Electromechanics, 2021, no. 2, pp. 64-69. doi: 10.20998/2074272X.2021.2.09. 